\title{
RPL5 wt Allele
}

National Cancer Institute

\section{Source}

National Cancer Institute. RPL5 wt Allele. NCI Thesaurus. Code C107653.

Human RPL5 wild-type allele is located in the vicinity of 1 p22.1 and is approximately $10 \mathrm{~kb}$ in length. This allele, which encodes 60 S ribosomal protein $L 5$, is involved in the formation of the 605 ribosome. Mutation of the gene is associated with Diamond-Blackfan anemia 6. 